\title{
Philosophical anthropology in postmodernism
}

\author{
Leila B. Omarova - Aydar M. Kalimullin - Ludmila Yu. Grudtsina - \\ Andrey V. Korzhuev - Maria Ye. Zhukova
}

DOI: 10.18355/XL.2018.11.03.07

\begin{abstract}
The approach to studying society in the postmodernist framework is relevant to understand postmodernist paradigm in contemporary philosophy. The rapid development of computerization and mass media in postmodern culture has been destroying the quality of human interaction with the surrounding environment and social reality, causes a feeling of losing touch with reality. This is due to the emergence of many virtual realities. The purpose of the article is to analyze the anthropological ideas in the philosophy of postmodernism. Postmodern anthropology is realized not only in the context of scientific revolution and internal form of culture but also as self-consciousness of modern civilization. Postmodernists prefer to discuss human beings as not whole self-contained individuals, units that may be broken down (divided), and call them 'dividuals,' beings or persons significantly distinct from their modern descendants, this being the best characteristic of the modern social state and contrasting to a Cartesian tradition. Methodologically the article is based on a systematic approach combining structural-functional, dialectical and hermeneutical methods. This approach allows us to reveal essential aspects of postmodern philosophy in their dialectical interrelation, to overcome constraints inherent in the heuristic potential of certain methodologies. The survey covers issues related both directly to the field of general theoretical postmodern philosophy and social sciences and makes a review on the researches on the human identity in the postmodern era. The analysis conducted made it possible to distinguish the main characteristics of postmodernism. The main intention of postmodernism considered is the crushing criticism of traditional values: humanism, rationalism, radicalism towards social structure and development, its rejection, denial of individuals' ability to be responsible for their actions, their inability to resist the power of supranational structures.
\end{abstract}

Key words: postmodernism, culture, human, value, discourse, philosophical analysis

\section{Introduction}

Postmodernism is a complex, heterogeneous socio-cultural and philosophical phenomenon, established in Western society by 1970 s and ' 80 s, and combining a variety of ideas. The term 'postmodern' is often used as a synonym for it although there is a certain difference between them due to the fact that postmodernism is explicated in several social spheres, i.e., as a cultural environment, as a philosophical construction, as a philosophy of art, as a form of mass consciousness, and, finally, as a paradigm feature of postindustrial society (Orekhovskaya, 2009). Evaluation judgments concerning postmodernism are also polyvariant and include a cultural situation of our time, as an outrageous art form; some perceive it as the neo - archaic, i.e., return to nihilism and decadence in the early 20th-century (Omarova, 2017). For this reason, the term, postmodern, is the most general one; it denotes the type of Western European culture self - identification, its lifestyle, as well as the system of the world value perception and the model of attitude to the world developed in postindustrial society.

Postmodern culture rejects all the values the modern period and proclaims new values: freedom of thought and action, pluralism, tolerance of different variety, rejection of the universal, the complete, the absolute. Compared to the era of Modern when knowledge was determined as a necessity in achieving a goal of mastering the 
world, postmodernists put forward the idea of interaction with the world. Thought, knowledge, and culture, in general, are increasingly determined by the language, discourse, and texts of past eras. After all, "our world is our language," therefore, neither culture as a whole, nor an individual can comprehend the real essence of things (Omarova, 2011).

The task of the new trend in philosophy is to understand the hidden meaning breaking away from the power of the language. It is necessary to debunk the pseudo-world created in the human mind by the modern media that imposes the truth that people should learn to think independently which is in the state's, economic's and political institution's interests.

The most well-known postmodernist concerns are 'deconstruction' and 'discourse.' Discourse is a specific set of texts, culture texts live their own lives, and deconstruction involves the close reading of texts in order to demonstrate that any given text has irreconcilably contradictory meanings, rather than being a unified, logical whole with just one sustainable meaning (Mankovskaya, 2000).

R. Rorty (2003), the postmodern's most gifted defender, expressed his opinion that contemporary religion and philosophy look at postmodernists as genres of literature; they are optional (one intellectual reads a lot of novels, the other is fond of poems. One of the purposes for intellectuals to be engaged in reading is to find out what goals it makes sense to strive for.

The truth is sublimated in 'deterritorialization' which implies that there is no a fixed place for a human in the society, for an author in the text, no boundaries between the author and the reader, and, finally, no demarcation line between scientific and extrascientific knowledge, between the rational and the irrational. The metaphor of the deterritorial has a connotation in common with Zen Buddhist saying belonging to Jiddu Krishnamurti that compares the truth with a country with no roads; the truth may be grasped, cognized, as many times as there are cognizers on their way to it (Ermilova, 2008).

The deterritorialization of postmodernists is filled with critical pathos in relation to any established structures and systems, whether or not they are social or theoretical and cognitive systems. The article of G. Deleuze and F. Guattari (2010) in "Capitalism and schizophrenia" is permeated by a revelatory criticism. Deterritorialization is considered there as a concept referring to anthropology and culture; with its basic quality associated with the lack of stability, certainty. Unstable diversity is expressed here in the metaphor of "schizophrenia." The persistent and violent ordering of social reality, the generalization of ideas, is not the goal of a human but of power. The long chapter "Treatise on Monadology: The War Machine," where they develop a theory of the state and the nomad war machine that counters it, is the impressionistic example of postmodernist prose with two epistemological models of the reality cognition. The first is the history of philosophical invariants; the second is the continuous variability. The second model is the postmodern one. It sublimates "deterritorial," boundless and whimsical mobility, wandering in the wilderness, not knowing the road; a motionless reality resembles an aversion to woods with their roots accreted. In these images there is a complete metaphor, impressionism, fluctuation, and non-verifiability of the plot, erasing the boundaries between objective research and subjective-poetic assessment (Deleuze, Guattari, 2010).

On the whole, the task of "schizoanalysis" is to make the social reality more pliable and plastic. It is in this sort of reality a "free, fun, lonely and irresponsible" schizoindividual can exist (Deleuze, Guattari, 2010), differing, certainly, from a clinical schizophrenic. The latter is treated in the hospital, and the first deliberately rejects any repressive canons of culture, slides through uncertainties, is guided by impulses and desires which he discusses openly. J. Baudrillard (2000) wrote about one of the riders

XLinguae, Volume 11, Issue 3, June 2018, ISSN 1337-8384, eISSN 2453-711X 
expiring en route because of his death. In death, he is able to set a pace so remarkable that the cycle outruns the train! The extreme phenomenon implicates both physics and metaphysics. This is the image that the author likes very much because it shows the growth of a hedonistic beginning, inherent in Western culture. Abandoned, hopelessly lost in his own solitude, Homo Virtuales, an eternal nomad of dreamy culture, cherishes his dream of meeting Other. His endless monologue sounds like the song of the sirens. The monologue on the integrity of the Dialogue with Other. Tirelessly, in a thousand tunes, modern Narcissus sings an enthusiastic hymn to Another (Baudrillard, 2000). However, the counterintuitive proposal of J. Baudrillard's provocative formula is worth considering: for he goes so far as to suggest that hospitality can be bad, cruel, selfish, and egotistical. The realization that some forms of hospitality resemble cannibalism is a welcome understanding of the element of power involved in the capitalized society.

\section{Research Methodology}

The methodological basis of the article is a systematic approach combining structuralfunctional, dialectical, and hermeneutical methods. This approach allows revealing essential aspects of the postmodern philosophy in their dialectical interrelation, to overcome the limitations inherent in heuristic possibilities of certain methodological directions.

When carrying out the survey, general methodological methods of comparison, analysis and synthesis, comparative-typological and specific-historical approaches have been used. Socio-philosophical, sociological, political and other scientific developments of both domestic and foreign researchers have also been studied.

In the course of the philosophical analysis of one of the extremely complex, and contradictory of the human problems in the philosophy of postmodernism, the system analysis of the postmodernist works has been applied; the methodology used allowed, on the one hand, to investigate the dialectics of anthropological ideas in the philosophy of postmodernism considered as an integral direction, on the other, to reveal an exceptional, special, understanding of the human place in the world of multiplicity of realities.

\section{Literature Review}

The essence of the anti-Cartesian "anthropodicy" is the statement of a person as a nonnatural creature, proving it on the grounds that the human brain is "the structure of structures," and a person is a "willing machine." Non-natural features are described by means of impersonality concepts, the experience of development, intensities, flows of desire, schizoid, migration, aesthetics of existence (Andrews et al., 2017). M. Foucault (1997) proves the impossibility of the issue of a human as an entity as the human dies, but structures remain. Such" structures " are primarily sexuality and eroticism, well described by G. Bataille (1997), G. Deleuze, F. Guattari (2010), M. Blanchot (1998), etc.

For M. Foucault (1997), who was one of the first to formulate the theory of "the death of the subject," it was obvious that the super emphasized human determinism predestinates the fate of the subject. Michel Foucault was a "cultural barometer" of the postmodern, so philosophical anthropology in his format primarily reconstructs any "abnormality," any attempt to leave and be outside the scope of the permissible. He believes that the attitude of insanity defines the level of social development and civility. The attitude of a person and society as a whole to the mad outside and inside oneself is the determinant of the level of development of human relations, including the maturity of the moral and ethical standards. In the case of the "death of the subject" this approach becomes the only possible as the reality remains only on the other side of the human mind. M. Foucault (1997) makes the assertion that madness, in this esteemed artistic form, brings the very question of our reason and civility to 
light. As he states “...the world that thought to measure and justify madness through psychology must justify itself before the madness, since in its struggles and agonies it measures itself by the excess of the works like those of Nietzsche, of Van Gogh, of Artaud. And nothing in itself, especially not what it can know of madness, assures the world that it is justified by such works of madness". His reflections on the condition of sanity in the modern world make him conclude that "lightning-flashes" in the works of art "open a void, a moment of silence, a question without an answer, [and] provoke a breach without reconciliation where the world is forced to question itself" (Foucault, 1997).

Following C. Levi-Strauss (1992), M. Foucault (1997) believes that rational consciousness, which occupied the sphere of madness with the help of psychology, is still forced to constantly justify itself before madness. And nowhere, least of all in understanding madness, does he find it certain that these creations of madness justify it. The world has to be constantly plunged into self-deception, build pseudo-rational pyramids of consciousness while trying to find the truth and freedom. Freedom is no longer conceived as the absence of constraint but as the utilization of the power which circulates in all relations, which is productive as much as it is constraining. Thus, M. Foucault's thought has shifted from the distinction between freedom and constraint to the distinction between freedom-as-power and domination. Foucault points out ways in which we are less free than we thought, but it's not power in general that makes us less free; rather, it's a specific form that power takes. Freedom remains on the other side of reality, still remaining the same attribute of madness and bringing it closer to the truth. It is vaguely hovering around any associated practices and concepts resembling the truth that accompanies all the words, thoughts and actions of the mad (Foucault, 1997). Another thing is that this freedom, despite its constancy, is fragile. It exists somewhere far away, on the horizon perceived, and disappears any time you try to define, distinguish, it. This is largely due to the mechanisms of perception, which do not correspond to the fact that they operate in the sphere of abnormality. Hence, it has to do with schizoanalysis, has something in common with deconstructionism in anthropology. This discourse of thought deconstructs not only the consciousness but also the unconscious, finally relativizing the nature of a person; personality as a result of its artistic justification obtains the features of the literary conventions.

The alleged M. Foucault's (2004) "archaeology of knowledge" continues the deconstruction of the myth about the individual as an ontological center, a particle possessing such fundamental characteristics as rationality, discreteness, mobility, and with no narrow ideological corridor possible. These characteristics, according to K. Popper (1992), an individual should have, i.e., a particle (his concept of 'entangled virtual particles') of the liberal system that seeks the dynamic balance.

According to M. Foucault (2004), human beings are not capable of explaining neither the unconscious, nor the systems of language controlling them, nor the topics which they focus, centralize on, nor their sexuality. "Archaeology of knowledge" defocuses the human's relation to the nonaccepted and nonrecognized laws of construction of the life, shows that a person is not able to understand what exactly creates and develops him as a human being, not able to consciously perceive the operational rules of the episteme (Foucault, 2004). The very possibility of critical awareness is not possible since the phenomenon is no longer associated with the cause that created it.

The problem of the "decentralization of the subject," developed by the structuralists, was developed by M. Foucault (1996) even in more specific form. From the autonomy of human consciousness, he moved to the idea of "discursive functions" of human consciousness. In his article "What is the author?" M. Foucault $(1996,1997)$ criticizes the concept of 'author' as a conscious and sovereign 'creator' of his own work. He then proceeds from a new understanding of the subject-object relationship developed in linguistics, psychoanalysis, and literature. The similar idea has been

XLinguae, Volume 11, Issue 3, June 2018, ISSN 1337-8384, eISSN 2453-711X 
expressed by G. Bataille (1997) through his idea that the abolition of the subject and the object is the only way not to end up with the state of things when the subject controls and dominates the object, i.e., to avoid the absurd pressure of One 's Self that wants to become everything.

Another poststructuralist, R. Barthes (2004), has a similar approach; he characterizes public opinion (the builder of any subjeca tivity) as the "middle-class consensus" and the dominance of prejudices. For him, the concept of "death of the author" is "Eureka moment," the culmination of philosophical creativity.

The problem of studying postmodern ideas is interdisciplinary and is in tha e focus of attention of representatives of various specialties: historians, philosophers, political scientists, sociologists, art historians, and linguists. For example, S.V. Kortunov (2009) examines the concept of postmodernism regarding international politics. He states that, in relation to international relations, postmodern agnosticism has transformed into legal relativism when the basic norms of international law (sovereignty, non-interference in the internal affairs of other states, refusal to use military force, etc.) started to be applied s,electively, depending on current political needs and specific situations " (Kortunov, 2009).

Russian science has accumulated a great theoretical potential for the analysis of postmodern concepts in general. Questions of the postmodern ideas impacting on all spheres of human activity have been in view of such Russian scientists as N.B. Mankovskaya (2000), G.I. Yermilova (2008), I.P. Ilyin (1996), V. Brainin-Passek (2002).

In theories of foreign authors, originating from different methodological positions such as R. Rorty (2003), J. Baudrillard (2000), C. Greber (2018), the postmodern philosophy ideas have been introduced in different anthropological and social proportions. In its most general form, the postmodern expresses its deep disappointment with the results of all previous human development, the loss of faith in a human and the humanism, reason, and progress, in all previous ideals and values. With mixed feelings of anxiety, regret, confusion, and pain, the humanity comes to realize that it will have to give up the dream of a bright future. Moreover, not only bright but the future whatsoever is becoming a problem. All the previous goals and objectives are now reduced to one, to survival. The postmodern man seems to feel out of his depth as if he were in zero gravity or the somnambulistic state and he cannot come out of it. Postmodernism manifests itself differently in every particular area of life and culture. Postmodern human refuses self-restraints and asceticism, so revered once in the protestant ethic. He is prone to living for the moment, never thinking too much about tomorrow and the more distant future. The main incentive for him is a professional and financial success (Razinsky, 2017). And this success should not come at the end of life, but as soon as possible. For this, the postmodern human is ready to give up and ignore any principles. The worldview of the postmodern person is deprived of a foothold because all forms of ideology look blurred and uncertain. They seem to be struck by some sort of inner passivity. This ideology is sometimes called "soft-ideology," that is, soft and gentle. It is neither left nor right, everything that previously was considered incompatible can peacefully coexist in it. This situation is largely due to the fact that the postmodern worldview is devoid of a completely stable internal core (Radjabov et al., 2017). In antiquity, such as mythology, in the middle ages, it was religion, in the era of modernity, it is, first, philosophy, and, then, science. Postmodernism debunked the prestige and authority of science but offered nothing in return complicating the problem of orientation in the world. In general, the attitude of the postmodern person can be defined as neofatalism. Its peculiarity is that a person no longer perceives himself as the master of his fate who relies on himself in everything, owes everything to himself. 


\section{Results and Discussions}

As a result of the survey conducted the following statements have been made:

1. Postmodernism rejects the traditional interpretation of philosophical knowledge. For example, it does not have a traditional distribution of the problems into the fields of ontology, the theory of knowledge, social philosophy, etc. (although we can talk about postmodern analogs of these areas). Postmodernism almost is not concerned with the familiar to philosophy problem fields like the structure of the world, the purpose of a human, the purpose of life, etc. It is interested in issues of another type: the role of gender in the knowledge of the world, the importance of science as a system of social coercion, symbolic meanings of different types of consumption, etc.

2. Postmodernism has practically never used the traditional philosophical, conceptual apparatus covering the categories like matter, consciousness, idea, necessity, essence, quantity, etc. Examples of postmodern terminology are deconstruction, logocentrism, narrative, nomadology, rhizome, etc. All of them are quite multifaceted in their identification. For example, 'deconstruction' is associated with the absence of permanent certainty in existence, or objective reality, and the cognition principle is to destruct stereotypes and constantly re-create the content of concepts. 'Logocentrism' is the attitude to the discourse which assumes that it is always possible to distinguish the central idea, the logical line of its development, in general; that each text has a clear, definite meaning. It refers to the tradition in science and philosophy that regards words and language as a fundamental expression of an external reality. Logocentrism for the postmodern is a negative feature that has been inherited from the philosophy of the previous time period. 'Rhizome' initially is a prostrate or subterranean root-like stem emitting roots and usually producing leaves at its apex; as a model for culture, resists the organizational structure of the root-tree system which charts causality along chronological lines, established connections between semiotic chains, organizations of power, and circumstances relative to the arts, sciences, and social struggles, presents history and culture as a map or wide array of attractions and influences with no specific origin or genesis. When the discourse is built on the principle of a rhizome, it means that any part of it can arbitrarily grow 'in any direction.'

3. Postmodernism, in general, follows the idea of post-metaphysical thinking, metaphysics, recognizing that unified systemic theory of world order cannot be created either by means of philosophy nor tools of science. Traditional metaphysics is opposed, in particular, to the" nomadology project» developed by G. Deleuze and F. Guattari (2010). Nomad is a member of a community of people who live in different locations, moving from one place to another in search of grasslands for their animals. Nomad's view of the world presupposes the image of an infinitely open space that has neither a center nor a certain organization. There is no clear clue? movement from the past to the future in it, the events that take place in it can be random, unpredictable. And the human in this world doesn't have any certain place; he is a nomad.

4. Postmodernism supports the methodological principle of plurality. It is expressed, firstly, through the idea that there is no, and cannot exist, a single method of cognition, the rules of thinking, research strategy, the way to study each subject depending on the situation in which the learner finds himself. Second, postmodernism denies the possibility of a sustainable knowledge of some sphere of reality, because nothing is repeated in the world. And, thirdly, it denies the so-called binary (two digits) logic according to which each statement is either correct or incorrect, objects either possess some properties or do not possess, i.e., it depends on the position of postmodernism, any unambiguous judgment impairs the idea of the object. Knowledge of some issue is always an infinite set of possible judgments about it.

5. Postmodernism believes that consciousness of a modern human is inevitably captured by stereotypes because the array of ideas about the world already having

XLinguae, Volume 11, Issue 3, June 2018, ISSN 1337-8384, eISSN 2453-711X 
been produced by civilization is very large. A "postmodern effort" is needed to get out of the burden of these representations and formulate one's own judgment. Therefore, postmodernism aims to be accessible, transparent, and paradoxical, and many of his ideas are directed on releasing thinking and making it more intense, soul-searching or re-appraisal of human values, turning conventional views into new ones.

\section{Conclusion}

The social ontology of postmodernism is a post-industrial or information society. The content of postmodern views is provided by the cultural atmosphere of the late twentieth century. Dialogism, cultural polyphony, pluralism and liberalism of modern Western society created the preconditions for the development of a radical methodology to understand history and society in relation to the Modern project. In the frames of this methodology, the core requirement of postmodernism to history has been developed: it doesn't have a common foundation, and for this reason, the individual prevails over the universal. Classical problems of social philosophy, such as the problem of progress, the relationship of the society and the human, social ethics, the laws of social development, the problem of power - all of them are interpreted according to the deconstructivist methodology.

The main intention of postmodernism is a crucial critique of traditional values: humanism, rationalism, radicalism in relation to social organizations and opposition, rejection of possibilities of the person to be responsible for his/her actions, inability to resist the power of the transpersonal structures. Hence, the permanent postmodern key note is associated with liberation from the oppression of power, traditional value regulators, customary norms, rules and social dependencies (Orekhovskaya, 2009). The method used by postmodernists to achieve the goal is the method of "micro narrative," a story about social, a story about stories. It goes without saying that these stories differ significantly from the existing images of the philosophy of history. Historiography of the twentieth century elaborated the idea that history is a process of natural change of epochs (Yermilova, 2008).

Postmodernists developed a picture of consciousness as a form of an integrated system of the human psychological states each element of which is correlated with other elements, and the introduction of new information also interrelated to the information obtained in the past. The advantage of this approach is its metaphysical minimization: the ontological problems related to the nature of consciousness and the nature of self-existence are not taken into account. A methodological assumption has been made that a person is a zombie (a depersonalized individual), a "reversible" schizophrenic, and schizophrenia has been declared as the "creative norm" of people's social life. Thus, a person in the modern world turns out to be a well-computerized consumption machine that does not have a sense of "top and bottom," "sky" and "earth." But do 'the virtual reality heralds' leave the door ajar for a person to make a conscious choice? Or does the modern human-bear only the idea, concept, of knowledge, and not the knowledge itself? The answer is not obvious, and the opinions of those who treat everything with "ontological doubt" diverge. However, we can express the point of view of a cautious optimist: a human still has that another chance to look beyond the veil of total unfreedom.

The materials of the article may be used with the aim of further studying and solving the debatable problems of modern social philosophy and philosophical anthropology. They also may be of certain interest and significance to those involved in research covering the processes of transformation of human values in the 21 st century and as the subject of further research. 


\section{Acknowledgement}

The work is performed according to the Program of Development of Federal StateFunded Educational Institution of Higher Education "Financial University under the Government of the Russian Federation" for 2020.

The work is performed according to the Russian Government Program of Competitive Growth of Kazan Federal University.

The publication has been prepared with the support of the "RUDN University Program 5-100".

\section{Bibliographic references}

ANDREWS, B. - WATSON, P.J. - CHEN, Z.J. - MORRIS, R.J. 2017. Postmodernism, positive psychology and post-traumatic growth within a Christian ideological surround. In: Journal of Positive Psychology, vol. 12, n. 5, pp. 489-500. ISSN: 1743-9760E-ISSN: 1743-9779.

BARTHES, R.G. 2004. Empire of Signs. Moscow: Praxis. ISBN 5-901574 -31-1.

BATAILLE, G. 1997. Inner Experience. St.Peterburg: Axiom. ISBN 5-86457-096-7.

BAUDRILLARD, J. 2000. The Transparency of Evil.by Jean. Moscow: Dobrosvet. ISBN: 978-5-8291-0898-4.

BLANCHOT, M. 1998. The Unavowable Community. Moscow: Moscow philosophical Foundation. ISBN 5-85133-053-8.

BRAININ-PASSEK, V. 2002. On the postmodernism, crisis of perception and new classics. In: New world of art, vol. 5, n. 28, pp. 7-10. ISBN: 978-5-902640-07-3.

DELEUZE, G. - GUATTARI, F. 2010. A thousand plateaus: capitalism and schizophrenia. Moscow: U-Faktoriya Astrel. ISBN: 978-5-9757-0527-3.

FOUCAULT, M. 1996. The Courage of Truth. Moscow: Kastal. ISBN 5-85374-006-7 FOUCAULT, M. 1997. Madness and Insanity: History of Madness in the Classical Age. St. Peterburg: Peter. ISBN 5-7914-0023-3.

FOUCAULT, M. 2004. Archaeology of Knowledge. St. Peterburg: humanitarian Academy. ISBN: 5-93762-034-8.

GREBER, C. 2018. Postmodernism and beyond in occupational therapy. In: Australian Occupational Therapy Journal, vol. 65, n. 1, pp. 69-72. ISSN: 0045-0766

ILYIN, I.P. 1996. Poststructuralism, Deconstructionism, Postmodernism. Moscow: Intrada. ISBN 5-87b04-035-5.

KONDRLA, P. - KRALIK, R. 2016. Authentic being and moral conscience. In: European Journal of Science and Theology, vol. 12, no. 4, pp. 155-164. ISSN 18410464.

KORTUNOV, S.V. 2009. Contemporary Russian Foreign Policy: the strategy of selective engagement. Moscow: Higher School of Economics. ISBN 5-7598-0637015 .

KRALIK, R.-TINLEY, S. J. 2017. Kierkegaard's Ethics as an Answer to Human Alienation in Technocratic Society. In: Communications-Scientific Letters of the University of Zilina, vol. 19, n. 1, pp. 25-29. ISSN1335-4205.

LENOVSKY, L. 2017. Identity as an instrument for interpreting the socio-cultural reality. 2015. In: European Journal of Science and Theology, vol. 11, no. 5, pp. 171184. ISSN 1841-0464.

LEVI-STRAUSS, C. 1992. The structure of the myth. In: Questions of philosophy, vol. 3, pp. 234-249. ISSN:0042-8744.

MANKOVSKAYA, N.B. 2000. The Aesthetics of Postmodernism. St Peterburg: Peter. ISBN 5-89329-237-5.

MAHRIK, T. 2015. Kierkegaard's existential ellipse of truth. In: European Journal of Science and Theology,vol. 11, n.4, pp.43-52.ISSN1841-0464.

XLinguae, Volume 11, Issue 3, June 2018, ISSN 1337-8384, eISSN 2453-711X 
OMAROVA, L.B. 2011. Measure of individual freedom in the information flows of the present. Humanities. In: The Bulletin of the Financial University, vol. 4, pp. 3137. ISSN: 2226-7867.

OMAROVA, L.B. 2017. Philosophical Format of Creative Freedom. In: Humanitarian Newsletter, vol. 10, n. 60, pp. 4-15. ISSN: 2306-8477.

OREKHOVSKAYA, N.A. 2009. The Role of Orthodoxy in the Formation of the Mass Consciousness of the Russian people. In: Bulletin of the Moscow Regional University, vol. 3, pp. 117-122. ISSN: 2072-8530.

PAVLIKOVA, M. 2017.Reading Auden as a Resource for Existential Reflection in a Society with Technocratic and Hedonistic Tendencies. In: CommunicationsScientific Letters of the University of Zilina, vol. 19, n. 1, pp. 39-43. ISSN 13354205.

POPPER, K. 1992. The Open Society and Its Enemies. Moscow: Phoenix. ISBN 585042-064-9.

RADJABOV, O.R. - GUSEYHANOV, M.K. - RADJABOVA, Z.K. LOBACHYOVA, Z.N. - RAMAZANOV, N.A. - MAGOMEDOVA, U.G. 2017. Modern aspects of science development: Synergetics and globalization. In: Journal of Engineering and Applied Sciences, vol. 12, n. 4, pp. 834-839. ISSN: 1816-949XEISSN: 1818-7803.

RAZINSKY, L. 2017. Psychoanalysis and Postmodernism: A Response to Dr. Jon Mills's "Challenging Relational Psychoanalysis: A Critique of Postmodernism and Analyst Selfdisclosure". In: Psychoanalytic Perspectives, vol. 14, pp. 356-363. ISSN: 1551-806XE-ISSN: 2163-6958.

RORTY, R. 2003. From Religion through Philosophy To Literature: the Path of Western Intellectuals. In: Questions of philosophy, vol. 3, pp. 30-41. ISSN: 00428744.

YERMILOVA, G.I. 2008. Postmodernism as a Phenomenon of Culture of the Late Twentieth Century. In: Cultural studies, vol. 4, pp. 242-256. ISSN: 2073-5588.

Words: 5143

Characters: 34294 (19,05 standard pages)

Senior Lecturer Leila B. Omarova

Department of Sociology, History and Philosophy

Financial University under the Government of the Russian Federation

49 Leningrad Avenue

125167, Moscow

leylaomarova1@gmail.com

Prof. Aydar M. Kalimullin, Dr.

Director of the Institute of Psychology and Education

Kazan (Volga region) Federal University

18 Kremlyovskaya Str., 420008 Kazan

Russia

kalimullin@yandex.ru

Prof. Ludmila Yu. Grudtsina, Dr.

Center for Educational Law,

Institute of Education Management of the Russian Academy of Education

5/16 Makarenko Str., 105062, Moscow

Russia

ludmilagr@mail.ru 
Prof. Andrey V. Korzhuev, Dr.

Department of Medical and Biological Physics

I M Sechenov First Moscow State Medical University (Sechenov university)

8 Trubetskaya Str., 119991 Moscow

Russia

akorjuev@mail.ru

Assistant Maria Ye. Zhukova

Department of Administrative and Financial Law

Peoples' Friendship University of Russia (RUDN University)

6 Miklukho-Maklaya Str., 117198 Moscow

Russia

mzh.law@gmail.com 